ROCZNIKI PEDAGOGICZNE

Tom 12(48), numer $4 \quad 2020$

DOI: https://doi.org/10.18290/rped20124-5

PRZEMYSŁAW EUGENIUSZ KANIOK

\title{
NASTOLETNI OJCOWIE
}

JAKO OPIEKUNOWIE I WYCHOWAWCY WŁASNYCH DZIECI

\author{
Chcesz, abym miłował . Trafiasz \\ do mnie przez dziecko, przez \\ maleńką córeczkę lub synka - \\ i mój upór słabnie. \\ Nie pozostaje nic z tej samotności, \\ którą usiłuję przeciwstawiać się Tobie [...] \\ (Wojtyła, 1979, s. 232).
}

\section{WPROWADZENIE}

Problematyka udziału nastoletnich ojców w opiece nad swoimi dziećmi i w ich wychowaniu stanowi aktualnie przedmiot rosnącego zainteresowania ze strony decydentów i społeczeństw (por. Kalil i in., 2005, s. 197). Jednym z powodów, dla którego uwaga wielu osób skupiona jest właśnie na tym zagadnieniu, są m.in. wynikające $\mathrm{z}$ nastoletniego ojcostwa negatywne konsekwencje o charakterze społecznym, ekonomicznym i zdrowotnym. W celu lepszego poznania natury oraz rozmiaru wspomnianych konsekwencji rozpoczęto prowadzenie badań naukowych w tym zakresie (Card i Wise, 1978, s. 199). Pomimo istniejących już opracowań w dalszym ciągu wiedza na temat nastoletnich ojców i ich dzieci jest, w przeciwieństwie do kwestii nastoletnich matek, mniej udokumentowana (Mollborn i Lovegrove, 2011, s. 3). Dlatego celem prezentowanego artykułu jest próba przedstawienia arbitralnie wybranych wyników badań, dzięki którym możliwe będzie poznanie rzeczywistego udziału nastoletnich ojców w opiece nad swoimi dziećmi i w ich wychowaniu.

Dr PrzemysŁaw Kaniok - Katedra Pedagogiki Specjalnej, Instytut Nauk Pedagogicznych, Uniwersytet Opolski; adres do korespondencji: ul. Oleska 48, 45-052 Opole; e-mail: kaniokp@ uni.opole.pl; ORCID: https://orcid.org/0000-0002-0792-4260. 
Analizując dane demograficzne dotyczące liczby nastoletnich ojców, warto zauważyć, że nie jest ona do końca znana. Jednym z powodów, dla których trudno jest oszacować populację nieletnich ojców, jest brak w aktach urodzeń dzieci informacji na temat wieku ich biologicznych ojców (por. Landry i Forrest, 1995, s. 159). Niemniej jednak, na podstawie dostępnych danych statystycznych, oszacowano że w roku 1996 tylko w samych Stanach Zjednoczonych nastoletni ojcowie stanowili 9\% populacji młodych chłopców, czyli 900 tysięcy mężczyzn w wieku od dwunastu do szesnastu lat, którzy zostali ojcami (Scott i in., 2012, s. 1). Ponadto, uwzględniając inne amerykańskie statystyki demograficzne dotyczące urodzeń i zgonów, można zauważyć, że w roku 1996 nastoletni ojcowie w wieku od piętnastego do dziewiętnastego roku życia stanowili $22,7 \%$ wszystkich rówieśników. Z kolei w roku 2014 grupa ta liczyła już zaledwie 11,3\% całej populacji chłopców w tym przedziale wiekowym (Hamilton i in., 2015, s. 46). Podobną tendencję można zaobserwować w Anglii i Walii, w których pomimo braku danych statystycznych na temat liczby nastoletnich ojców Brytyjski Krajowy Urząd Statystyczny odnotował spadek urodzeń dzieci, których matkami były nastolatki. Trend ten utrzymuje się już od 1969 r., kiedy to liczba matek będących w wieku poniżej osiemnastego roku życia wyniosła 45495 osób. Z kolei w roku 2016 wspomniana populacja liczyła już tylko 18076 dziewcząt (Office for National Statistics, 2018, s. 6). Chociaż nie są znane dokładne dane statystyczne dotyczące liczby nastoletnich ojców w Wielkiej Brytanii, to na podstawie innych materiałów źródłowych Brytyjskiego Krajowego Urzędu Statystycznego można wywnioskować, że w roku 2016 w zalegalizowanych związkach małżeńskich, w których rodzice nie przekroczyli dwudziestego roku życia, urodziło się 114 dzieci. Natomiast w związkach niezalegalizowanych, w których partnerzy mieli mniej aniżeli dwadzieścia lat, liczba nowonarodzonych dzieci wyniosła 5451 (por. Office for National Statistics, 2017). Na podstawie powyższych informacji można jedynie domniemywać, że w roku 2016 ojców poniżej dwudziestego roku życia było około 5 565. Natomiast rok wcześniej, czyli w roku 2015, biorąc pod uwagę 112 urodzeń dzieci w związkach formalnych i 5849 urodzeń w związkach nieformalnych, ojców w tym wieku było 5961 (por. Office for National Statistics, 2016). Dane te mogą jednak nie odzwierciedlać rzeczywistego obrazu nastoletnich ojców z uwagi na fakt, że uwzględniają one jedynie tych mężczyzn, którzy zostali wymienieni w aktach urodzeń. Mając na względzie jedynie dwa powyższe lata, wskaźnik poczęcia dzieci przez osoby poniżej dwudziestego roku życia charakteryzował się w Wielkiej Brytanii tendencją 
spadkową. Również w Polsce liczba nastoletnich ojców maleje. Najlepiej obrazują tę tendencję dane Głównego Urzędu Statystycznego, dzięki którym można stwierdzić, że w roku 2014 liczebność nowo narodzonych dzieci, których rodzice mieli maksymalnie dziewiętnaście lat, wyniosła 1288 noworodków (Główny Urząd Statystyczny, 2015, s. 270). Natomiast w roku 2016 liczba ta była już o 17,62\% mniejsza i wyniosła 1061 urodzeń (Główny Urząd Statystyczny, 2017, s. 278). Na podstawie powyższych statystyk można jedynie przypuszczać, że populacja nastoletnich ojców jest zbliżona do liczby ich nowo narodzonych dzieci, chociaż podobnie jak w przypadku innych krajów, nadal może być nieoszacowana.

Mając już pewne wyobrażenie na temat skali zjawiska nastoletniego ojcostwa, warto wyjaśnić znaczenie samego terminu „nastoletni ojciec”. Jak twierdzi E.H. Wei nieletni ojcowie to „mężczyźni, którzy podczas swoich nastoletnich lat (pomiędzy trzynastym a dziewiętnastym rokiem życia) płodzą dzieci [...]" (Wei, 2000, s. 625). Z kolei M.S. Kiselica w encyklopedii zatytułowanej Chtopięctwo w Ameryce napisal, że nastoletni ojciec jest „[...] mężczyzną, który staje się rodzicem w wieku pomiędzy dwunastym a dwudziestym rokiem życia" (Kiselica, 2001, s. 246). Podobną definicję nastoletnich ojców zaproponowali M.A. Pirog, H. Jung i D. Lee. Określili oni małoletnich ojców jako ,[...] tych, którzy w chwili narodzin ich pierwszego dziecka byli w wieku dziewiętnastu lub mniej lat" (Pirog i in., 2017, s. 324). Amerykańscy naukowcy, prowadzący badania jakościowe, definiują fakt bycia nastoletnim ojcem jako ,zostanie biologicznym rodzicem przed dwudziestym rokiem życia” (Xie i in., 2001, s. 493) lub bycie „ojcem, bądź też uznanym za ojca, który jest w wieku poniżej dwudziestego roku życia” (Hendricks i in., 1984, s. 183). Z uwagi na brak danych związanych z dokładną liczbą nastoletnich ojców, nie można sformułować ich bardziej szczegółowej definicji, która uwzględniałaby różnorodne aspekty nieletniego ojcostwa. Stąd też w większości dostępnych definicji nastoletnich ojców szczególną uwagę zwracano na kwestię ich wieku (Morrell, 2007, s. 198).

\section{NASTOLETNI OJCOWIE - UCZESTNICY PROCESU WYCHOWANIA}

Przez wiele lat zagadnienie nastoletnich ojców było albo marginalizowane, stanowiąc jedynie mało znaczący aspekt nieletniego macierzyństwa, albo przedstawiane $\mathrm{w}$ negatywnym świetle, wynikającym ze stereotypowego 
postrzegania ich (por. Tuffin i in., 2010, s. 486). Odzwierciedleniem takiego status quo były opracowania naukowe, w których nastoletni ojcowie byli określani mianem „niechętnych uczestników procesu wychowania swoich dzieci" (Miller, 1997, s. 61), osób niezainteresowanych ich sprawami i niezaagażowanych w ich życie (por. Strug i Wilmore-Schaeffer, 2003, s. 505) oraz unikających swoich obowiązków ze względu na niedbanie o dobro swojej rodziny (por. Parikh, 2005, s. 14). Wbrew pojawiającym się w powyższych badaniach stereotypowym opiniom istnieją także inne badania, których wyniki pozwalają stwierdzić, że większość nastoletnich ojców, pomimo że nie mieszka ze swoimi dziećmi (Pirog i Magee, 1997, s. 720), nadal przejawia zaangażowanie $\mathrm{w}$ opiekę nad nimi i w ich wychowanie (Maiden, 2013, s. 63). Wraz z rozwojem dzieci zaangażowanie to ulega osłabieniu. Świadczą o tym m.in. wyniki badań, w których zaobserwowano, że w pierwszym miesiącu życia dzieci opiekę nad nimi sprawowało $60 \%$ nastoletnich ojców. Natomiast w 42 miesiącu życia potomstwa populacja nieletnich ojców, angażujących się w opiekę, zmalała do zaledwie 25\% (Larson i in., 1996, s. 285). Trend w zakresie angażowania się nastoletnich mężczyzn w opiekę nad swoimi dziećmi potwierdzają inne, bardziej aktualne statystyki, w świetle których ponad połowa nieletnich mężczyzn (56\%) nie zamieszkuje ze swoimi nowo narodzonymi dziećmi i ich matkami (Scott i in., 2012, s. 3), lecz jak sami twierdzą - są ojcami zaangażowanymi w sprawy swoich dzieci m.in. poprzez odwiedzanie ich każdego dnia lub każdego tygodnia. Ponadto deklarują oni pozostawanie w bliskich relacjach ze swoimi dziećmi, opiekując się nimi przez kilka dni lub kilka miesięcy, wykazując się przy tym takimi umiejętnościami, jak karmienie, przebieranie, kąpanie, bawienie się czy chodzenie z nimi do lekarza (za: Kiselica, 2008, s. 51). Niezależnie od przeobrażeń zachodzących w sposobie podchodzenia nastoletnich ojców do obowiązków rodzicielskich warto dokonać charakterystyki ich aktualnego udziału w opiece nad dziećmi i w ich wychowaniu.

Udział ojców w opiece nad dziećmi i w ich wychowaniu uważany jest za pojęcie charakteryzujące się swoistą złożonością, dynamizmem i wielowymiarowością (Carbera i in., 2014, s. 336; McWayne i in., 2008, s. 901; Palkovitz, 2007, s. 191; Hawkins i in., 2002, s. 184; Lamb i in., 1985, s. 883). Jedną z najczęściej wykorzystywanych $\mathrm{w}$ badaniach naukowych kategoryzacji udziału ojców jest ta, którą sformułowali M.E. Lamb, J.H. Pleck, E.L. Charnov oraz J.A. Levine (Lamb i in., 1985, 1987). Wspomniani naukowcy wyróżnili trzy obszary udziału ojców, do których należą interakcja (z ang. interaction), osiągalność (z ang. availability) i odpowiedzialność 
(z ang. responsibility) (Lamb i in., 1985, s. 884). W późniejszym okresie słowo „interakcja” zaczęto zastępować słowem „zaangażowanie” (z ang. engagement), a słowo „osiągalność” wyrazem „dostępność” ( $\mathrm{z}$ ang. accessibility) (por. Pleck, 2010, s. 59). Termin „zaangażowanie” oznacza „[...] rodzaj udziału ojców w opiece nad dziećmi, obejmujący swoim znaczeniem czas, jaki mężczyźni poświęcają na rzeczywistą interakcję z nimi w formie «jeden na jeden» poprzez karmienie ich, odrabianie $\mathrm{z}$ nimi lekcji lub wspólną zabawę w ogrodzie. Ten rodzaj udziału [...] nie obejmuje czasu spędzanego z dzieckiem na czynnościach związanych z funkcjonowaniem gospodarstwa domowego lub czasu, w którym ojcowie przebywają w pomieszczeniach, obok których bawią się ich dzieci" (Lamb, 2000, s. 31). Drugim rodzajem udziału ojców jest „dostępność”, na którą „,[...] składają się zajęcia charakteryzujące się niskim poziomem interakcji rodzic - dziecko. Dotyczą one raczej dostępności rodziców względem swoich dzieci, aniżeli wchodzenia w bezpośrednią interakcję z nimi. Egzemplifikacją tego typu udziału ojców jest gotowanie przez rodzica posiłku w kuchni w momencie, kiedy dziecko samo bawi się $\mathrm{w}$ pokoju obok lub w tym samym pomieszczeniu, w którym przebywa rodzic" (tamże). Ostatnim komponentem udziału ojców jest odpowiedzialność, która „odzwierciedla zakres, w jakim rodzic ponosi całkowitą odpowiedzialność za dobrostan psychofizyczny dziecka i opiekę nad nim" (tamże). Odpowiedzialność obejmuje działania związane z podejmowaniem decyzji o tym, kiedy dziecko powinno udać się do lekarza pediatry, umówieniem go na wizytę i upewnieniem się, że na nią pójdzie. Dotyczy ona również takich działań, które polegają na organizacji opieki nad dzieckiem, zapewnieniu mu odzieży, czynnościach pielęgnacyjnych w sytuacji, kiedy jest chore. Termin „odpowiedzialność” wykracza swoim znaczeniem poza samo pomaganie i zapewnianie dziecku opieki. Większość czasu, przez jaki rodzic czuje się odpowiedzialny za dziecko, wcale nie sprowadza się do jego bezpośredniego kontaktu z nim. Dlatego badacze mogą łatwo przeoczyć w swoich badaniach ten rodzaj udziału ojców (por. tamże). W wyniku przeprowadzonej przez J. Plecka ponownej analizy powyższego konstruktu teoretycznego, zaproponował on pięć komponentów udziału ojców, do których należą: „1. Pozytywne działania ojców, związane z ich zaangażowaniem $\mathrm{w}$ życie dzieci ( $\mathrm{z}$ ang. positive engagement activities), polegające na bardziej intensywnej interakcji z nimi, sprzyjającej ich rozwojowi. 2. Ciepło i wrażliwość ( $\mathrm{z}$ ang. warmth and responsiveness). 3. Kontrola ( $\mathrm{z}$ ang. control), polegająca na nadzorze dziecka i podejmowaniu decyzji dotyczących jego osoby. 4. Pośrednia opieka nad dzieckiem ( $\mathrm{z}$ ang. indirect care), obejmująca dzia- 
łania podejmowane przez ojca na rzecz dziecka, niepociągające za sobą wchodzenia $\mathrm{w}$ interakcję $\mathrm{z}$ nim. Pośrednia opieka ojcowska nad dzieckiem może mieć wymiar materialny lub społeczny. Do form materialnej opieki pośredniej należy kupowanie i zapewnianie dziecku dóbr i usług. Natomiast wśród form społecznej opieki pośredniej wyróżnić można układanie relacji z rówieśnikami dziecka oraz instytucjami, z którymi ma ono styczność. Do tej formy opieki pośredniej nie należy zdobywanie przez ojca środków do życia. 5. Odpowiedzialność w zakresie monitorowania przez ojca tego, czy potrzeby przejawiane przez dziecko w czterech wcześniejszych komponentach udziału ojców, poza tymi, które zaspokaja sam ojciec, są zaspokajane"(Pleck, 2010, s. 67).

Chociaż temat nastoletnich ojców zaczął się pojawiać w literaturze przedmiotu na przełomie lat 70 . i 80 . XX wieku, kiedy to zaobserwowano wzrost zainteresowania badaczy problematyką nastoletniego macierzyństwa, to i tak był on przedmiotem zaledwie kilku publikacji naukowych, w których przedstawiono jedynie zarys problemu. Za początek rozważań poświęconych nastoletniemu ojcostwu uznaje się wydaną w 1986 r. publikację pod redakcją A. Elstera i M.E. Lamba, zatytułowaną Nastoletnie ojcostwo (oryg. tytuł Adolescent fatherhood). Stanowiła ona pierwsze opracowanie, w którym dokonano krytycznego przeglądu literatury z zakresu nauk społecznych i nauk o zdrowiu, poświęconej młodym ojcom, zwiększając tym samym społeczną świadomość dotyczącą problemów, z jakimi musieli się oni mierzyć (por. Kiselica i Kiselica, 2017). Poruszono w niej m.in. takie kwestie, jak radzenie sobie przez ojców z dylematami dotyczącymi adolescencji, uczenie się przez nich ról związanych ze swoją płcią, stosowanie przez nich antykoncepcji, przeżywany przez nich stres a sposoby radzenia sobie z nim, kwestia ukończenia przez nich szkoły średniej, ich zachowania rodzicielskie, stawanie się rodzicem, przypadki stosowania przez nich przemocy względem swoich dzieci, towarzyszące im problemy kliniczne, ich wzajemna współpraca oraz pełniona przez nich rola w życiu dzieci z perspektywy historycznej i obowiązujących przepisów prawa (por. Elster i Lamb, 1986).

Wątek zaangażowania nastoletnich ojców w opiekę nad swoimi dziećmi i w ich wychowanie w percepcji ich samych, nastoletnich matek oraz babć z obu stron został podjęty przez L.M. Rhein'a oraz jego zespół. W badaniach udział wzieło 173 nastoletnich ojców, 167 nastoletnich matek, 76 babć ze strony nastoletnich ojców oraz 79 babć ze strony nastoletnich matek. W wyniku przeprowadzonych badań ustalono, że nastoletni ojcowie zdecydowanie rzadziej od swoich partnerek oraz babć z obu stron uważają, że powinni być 
obecni przy porodzie dziecka, zapewniać mu wsparcie finansowe, karmić je, bawić się z nim lub jeździć do lekarza. W porównaniu z 93\% matek, które są przekonane o konieczności uczestnictwa ich nastoletnich partnerów w powyższych czynnościach opiekuńczo-wychowawczych, tylko 58\% ojców zgodziło się z tym stanowiskiem. Ponadto nastoletni ojcowie byli bardziej skłonni opowiadać o swoim finansowym wspieraniu dzieci, aniżeli wynikało to $\mathrm{z}$ relacji ich nastoletnch partnerek. Mniej niż połowa nastoletnich mężczyzn (33\%) deklarowała udzielanie dzieciom wspomnianej pomocy przynajmniej raz tygodniu. W toku dalszych analiz ustalono, że większość nastoletnich matek twierdziła, że $65 \%$ ojców ich dzieci ubiera je, a $74 \% \mathrm{z}$ nich bawi się z nimi przynajmniej raz w tygodniu. W przypadku grupy matek, które oceniły zaangażowanie swoich partnerów w opiekę nad swoimi dziećmi i w ich wychowanie jako sporadyczne, oni sami byli skłonni lepiej oceniać swój udział w ubieraniu ich oraz bawieniu się z nimi. Zdaniem matek $70 \%$ nastoletnich ojców nigdy nie karmiło swoich dzieci. Z kolei 73\% nastoletnich ojców twierdziło, że karmiło je przynajmniej raz w tygodniu (Rhein i in., 1997, s. 247).

Kontynuacją wątku udziału nastoletnich ojców w opiece nad własnymi dziećmi było amerykańskie opracowanie autorstwa S. Mollborn oraz P. Lovegrove'a z 2011 r., którzy wykorzystując Badania Longitudinalne z Zakresu Wczesnego Dzieciństwa oraz Kontroli Urodzeń (z ang. The Early Childhood Longitudinal Study - Birth Control) na próbie 14 tysięcy dzieci urodzonych w 2001 r., postanowili ukazać znaczenie niepełnoletnich ojców w ich życiu. Badaczom udało się ustalić, że nastoletni ojcowie niezamieszkujący ze swoimi dziećmi, deklarowali swoje zaangażowanie we wspólne zabawy oraz sprawowanie nad nimi opieki. Nie stwierdzono także żadnych istotnych różnic między nastoletnimi a dorosłymi ojcami w zakresie poziomu ich zaangażowania w opiece nad ich dziećmi (Mollborn i Lovegrove, 2011, s. 18).

Kwestia nastoletnich ojców i ich udziału w opiece nad dziećmi była pobocznym wątkiem $w$ badaniach jakościowych autorstwa S. Madiby oraz C. Nsiki z Republiki Południowej Afryki. Tematem badań były sposoby postrzegania ojcostwa przez nastoletnich ojców oraz związane $z$ nim doświadczenia na przykładzie wiejskich regionów w Republice Południowej Afryki. Udział w nich wzięło 25 nastoletnich ojców uczęszczających do szkół, z którymi przeprowadzono wywiady pogłębione. W wyniku przeprowadzonych badań ich autorzy ustalili, że dla większości nastoletnich ojców udział w opiece nad dziećmi oznaczał zaspokojenie potrzeb materialnych dziecka, spędzanie z nim wolnego czasu oraz karmienie go. Ponieważ żaden z ojców 
nie mieszkał ze swoim dzieckiem, żadna z czynności opiekuńczych nie była przez nich realizowana, przez co ich zaangażowanie sprowadzało się jedynie do wsparcia finansowego dziecka. Niektórzy nastoletni ojcowie nie byli zaangażowani $\mathrm{w}$ życie swoich dzieci z powodu różnych innych przeszkód, takich jak konflikt z matką dziecka, brak pieniędzy lub też brak czasu, wynikający z konieczności ich własnej edukacji (Madiby i Nsiki, 2017, s. 504).

\section{PODSUMOWANIE}

Reasumując przywołane wyniki badań empirycznych, warto podkreślić, że problematyka udziału nastoletnich ojców w opiece nad dziećmi oraz w ich wychowaniu stanowiła w nich zarówno wiodący, jak i poboczny wątek badawczy. Chociaż liczba nastoletnich ojców w Polsce i za granicą charakteryzuje się tendencją spadkową, to jednak zagadnienie to skupia uwagę wielu badaczy m.in. ze względu na negatywne konsekwencje o charakterze społecznym, ekonomicznym i zdrowotnym. Na podstawie przedstawionych w niniejszym artykule wyników badań można stwierdzić, że w większości z nich nastoletni ojcowie przejawiali zainteresowanie sprawami swoich dzieci, a także deklarowali zaangażowanie w opiekę nad nimi nawet wtedy, kiedy nie zamieszkiwali wspólnie. Po drugie, można zauważyć, że przed przyjściem dzieci na świat większość nastoletnich ojców deklaruje gotowość do zapewnienia im wsparcia finansowego i udziału w opiece nad nimi. Zapał ten jednak mija wraz z pojawieniem się na świecie dziecka oraz jego dalszym rozwojem. Trzecim wnioskiem, płynącym z zaprezentowanych wyników badań, jest stwierdzenie, że wszelkie wypowiedzi nastoletnich ojców na temat swojego znaczącego zaangażowania w życie dzieci, poddane weryfikacji ze strony ich partnerek, mogą okazać się nieprawdą. Niezależnie od oceny ich udziału $\mathrm{w}$ opiece nad ich własnymi dziećmi warto pamiętać, że nieustanne zachęcanie do większego zaangażowania w życie ich dzieci jest kluczowym warunkiem poprawy zarówno ich wzajemnych relacji, jak i dobrostanu psychofizycznego samych pociech.

\section{BIBLIOGRAFIA}

Cabrera, N.J., Fitzgerald, H.E., Bradley, R.H., Roggman, L. (2014). The ecology of fatherchild relationships: An expanded model. Journal of Family Theory and Review, 6(4), 336-354. 
CARD, J.J., WISE, L.L. (1978). Teenage mothers and teenage fathers: The impact of early childbearing on the parents' personal and professional lives. Family Planning Perspectives, 10(4), 199-205.

Elster, A.B., LAmB, M.E. (red.) (1986). Adolescent fatherhood. Hillsdale-New Jersey: Lawrence Erlbaum Associates, Inc., Publishers.

GŁówny URZĄD Statystyczny (2015). Rocznik demograficzny. Warszawa: Zakład Wydawnictw Statystycznych.

GŁÓWNy URZĄD STATYSTYCZnY (2017). Rocznik demograficzny. Warszawa: Zakład Wydawnictw Statystycznych.

Hamilton, B.E., Martin, J.A., Osterman, M.J.K., Curtin, S.C., Mathews, T.J. (2015). Births: Final data for 2014. National Vital Statistics Reports, 64(12), 1-64.

Hendricks, L.E., Montgomery, T.A., Fullilove, R.A. (1984). Educational achievement and locus of control among black adolescent fathers. Journal of Negro Education, 53(2), 182-188.

Hawkins, A.J., Bradford, K.P., Palkovitz, R., Christiansen, S.L., Day, R.D., Call, V.R. (2002). The Inventory of Father Involvement: A pilot study of a new measure of father involvement. The Journal of Men's Studies, 10(2), 183-196.

Kalil, A., Ziol-Guest, K.M., Coley, R.L. (2005). Perceptions of father involvement patterns in teenage-mother families: Predictors and links to mothers' psychological adjustment. Family Relations, 54(2), 197-211.

Kiselica, M.S. (2001). Fathers, Adolescent. W: P.F. Clement, J.S. ReInier (red.), Boyhood in America. An Encyclopedia (s. 246-250). Santa Barbara-Denver-Oxford: ABC Clio.

KiselicA, M.S. (2008). When boys become parents: Adolescent fatherhood in America. New Brunswick: Rutgers University Press.

Kiselica, A.M., KiselicA, M.S. (2017). Teenage fathers. Childhood Studies. DOI: 10.1093/OBO/ 9780199791231-0122. https://www.oxfordbibliographies.com/view/document/obo-9780199791 231/obo-9780199791231-0122.xml (dostęp: 15.05.2020).

LANDry, D.J., Forrest, J.D. (1995). How old are U. S. fathers. Family Planning Perspectives, 27(4), 159-165.

LAmB, M.E. (2000). The history of research on father involvement. An overview. Marriage and Family Review, 29(2-3), 23-42.

Lamb, M.E., Pleck, J.H., Charnov, E.L., Levine, J.A. (1985). Paternal behavior in humans. American Zoologist, 25(3), 883-894.

LAmb, M.E., Pleck, J.H., Charnov, E.L., Levine, J.A. (1987). A biosocial perspective on paternal behavior and involvement. W: J.B. LANCASter, J. Altman, A. Rossi (red.), Parenting across the lifespan (s. 111-142). New York, NY: Academic Press.

Larson, N.C., Hussey J.M., Gillmore, M.R., Gilchrist, L.D. (1996). What about dad? Fathers of children born to school-age mothers. Families in Society. The Journal of Contemporary Human Services, 77(5) 279-289.

MadiBA, S., Nsiki, C. (2017). Teen father's perceptions and experiences of fatherhood: A qualitative exploration with in-school teen fathers in a rural district in South Africa. Current Pediatric Research, 21(3), 501-506.

MAIDEN, B.S. (2013). The lived experiences of the adolescent father in Northern Virginia. Praca doktorska. Falls Church, Virginia: the Virginia Polytechnic Institute and State University. https://vtechworks.lib.vt.edu/bitstream/handle/10919/23868/Maiden_BS_D_2013.pdf?sequen $\mathrm{ce}=1$ (dostęp: 10.12.2018). 
MCWAyne, C., CAMPos, R., OWSIANIK, M. (2008). A multidimensional, multilevel examination of mother and father involvement among culturally diverse Head Start families. Journal of School Psychology, 46(5), 551-573.

Miller, D.B. (1997). Adolescent fathers: what we know and what we need to know. Child and Adolescent Social Work Journal, 14(1), 55-69.

Mollborn, S., Lovegrove, P.J. (2011). How teenage fathers matter for children: Evidence from the ECLS-B. Journal of Family Issues, 32(1), 3-30.

Morrell, R. (2007). Fatherhood. Teenage. W: M. Flood, J.K. Gardiner, B. Pease, K. Pringle (red.), International encyclopedia of men and masculinities (s. 197-198). Oxon-New York: Routledge.

OfFice fOR NATIONAL Statistics. (2016). Births by parents ' characteristics: 2015. https://www.ons. gov.uk/file?uri=/peoplepopulationandcommunity/birthsdeathsandmarriages/livebirths/datasets/birt hsbyparentscharacteristics/2015/birthsbyparentscharacteristics2015v2.xls; (dostęp: 28.09.2018).

OfFice FOR NATIONAL StATiSTiCS. (2017). Births by parents ' characteristics: 2016. https://www.ons. gov.uk/file?uri=/peoplepopulationandcommunity/birthsdeathsandmarriages/livebirths/datasets/birt hsbyparentscharacteristics/2016/birthsbyparentscharacteristics2016.xls (dostęp: 28.09.2018).

OfFice fOr NATiOnAL StATistics. (2018). Conceptions in England and Wales: 2016.

PAlkovitz, R. (2007). Challenges to modeling dynamics in developing a developmental understanding of father-child relationships. Applied Developmental Science, 11(4), 190-195.

PARIKH, S.S. (2005). The other parent: A historical policy analysis of teen fathers. Praxis. Where Reflection \& Practice Meet, 5, 13-21.

Piorg, M.A., Jung, H., LeE, D. (2017). The changing face of teenage parenthood in the United States: Evidence from NLSY79 and NLSY97. Child Youth Care Forum, 47, 317-342.

Pirog, M., Magee, C. (1997). High school completion: The influence of schools, families and adolescent parenting. Social Science Quarterly, 78(3), 710-724.

PleCK, J.H. (2010). Paternal involvement: Revised conceptualization and theoretical linkages with child outcomes. W: M.E. LAMB (red.), The role of the father in child development (s. 5893). Hoboken, New Jersey: John Wiley \& Sons Inc.

Rhein, L.M., Ginsburg, K.R., Schwarz, D.F., Pinto-Martin, J.A., Zao, H., Morgan, A.P., SLAP, G.P. (1997). Teen father participation in child rearing: family perspectives. Journal of Adolescent Health, 21(4), 244-252.

Scott, M.E., Steward-Streng, N.R., Manlove, J., Moore, K.A. (2012). The characteristics and circumstances of teen fathers: At the birth of their first child and beyond. Child Trends. Research Brief, June, 1-6.

Strug, D., Wilmore-Schaeffer, R. (2003). Fathers in the social work literature: policy and practice implications. Families in Society: The Journal Contemporary Social Services, 84(4), 503-511.

Tuffin, K., Rouch, G., FrewIN, K. (2010). Constructing adolescent fatherhood: responsibilities and intergenerational repair. International Journal for Research, Intervention and Care, 12 (5), 485-498.

Wei, E.H. (2000). Teenage fathers. W: L. BAlter (red.), Parenthood in America. An Encyclopedia, vol. 1 (s. 625-628). Santa Barbara-Denver-Oxford: ABC Clio.

WojtyŁa, K. (1979). Poezje i dramaty. Kraków: Znak. 
XIE, H., CAIRnS, B.D., CAIRns, R.B. (2001). Predicting teen motherhood and teen fatherhood. Social Development, 10(4), 488-509.

\section{NASTOLETNI OJCOWIE JAKO OPIEKUNOWIE I WYCHOWAWCY WŁASNYCH DZIECI}

\section{STRESZCZENIE}

Problematyka udziału nastoletnich ojców w opiece nad swoimi dziećmi i w ich wychowaniu stanowi aktualnie przedmiot rosnącego zainteresowania ze strony decydentów i społeczeństw. Celem prezentowanego artykułu jest przedstawienie arbitralnie wybranych wyników badań empirycznych, dzięki którym możliwe będzie poznanie udziału nastoletnich ojców w opiece nad dziećmi i w ich wychowaniu. Na podstawie przywołanych w niniejszym artykule wyników badań można stwierdzić, że większość nastoletnich ojców przejawia zainteresowanie sprawami swoich dzieci, a także deklaruje zaangażowanie w opiekę nad nimi nawet wtedy, kiedy nie mieszkają razem $\mathrm{z}$ nimi.

Słowa kluczowe: rodzina; nastoletni ojcowie; dzieci; udział; opieka; wychowanie.

\section{ADOLESCENT FATHERS AS CAREGIVERS AND EDUCATORS OF THEIR CHILDREN}

\section{SUMMARY}

The issue of adolescent fathers' involvement in care and education of their children constitutes the subject of the growing interest of policymakers and societies. The main aim of this study is to present arbitrarily selected results of empirical research, which will allow ascertaining adolescent fathers' involvement in children's care and education. Based on the cited research results, it can be stated that most adolescent fathers are interested in their children's affairs as well as declare their commitment to care for them even when they do not live with them.

Keywords: family; adolescent fathers; children; involvement; care; education. 